Arq. Bras. Med. Vet. Zootec., v.70, n.4, p.1036-1044, 2018

\title{
Effect of exercise on cardiovascular parameters in search and rescue-trained dogs
}

[Efeito do exercício sobre parâmetros cardiovasculares em cães em treinamento de busca, resgate e salvamento]

\author{
P.O.P.R. Santos, E.A. Santos, A.C. Reis, A.M.M.R. Santos, M.C.C. Kuster,
} L.O. Trivilin, K.P. Aptekmann*

Universidade Federal do Espírito Santo - Centro de Ciências Agrárias - Alegre, ES

\begin{abstract}
Physical activity alters the cardiovascular system of dogs, depending on the exercise characteristics and the animal's physical conditioning. Little is known about the cardiovascular changes in rescue-trained dogs. This study evaluated the cardiovascular responses to a search and rescue exercise session to differentiate these alterations from cases of exhaustion or some possible pathology. Nine healthy rescuetrained dogs that trained for at least one year were used. Seven German Shepherds and two Belgian Shepherd Malinois were evaluated twice, immediately before exercise (M0) and immediately after a 20minute training (M1). Electrocardiographic, echocardiographic, and systemic blood pressure (SBP) measurements were performed at each evaluation. Heart rate was evaluated in three moments, M0, M1 and five minutes after the end of the physical activity (M2). The results indicated that training increased oxygen demand and significantly increased cardiac output, left ventricular volume in diastole and aortic artery diameter, and the contraction force with the increased mitral annular motion without impairing systolic and diastolic cardiac functions. Heart rate values immediately and five minutes after exercise were similar to baseline values. Training did not alter SBP and the electrocardiographic parameters. The present study indicated good cardiac performance to the physical effort of rescue-trained dogs and reduced the chances of poor performance and the occurrence of sudden death caused by exercise in response to the pattern of activity performed.
\end{abstract}

Keywords: working dog, blood pressure, echocardiography, electrocardiography, exercise physiology

\section{RESUMO}

A atividade física acarreta diversas mudanças no sistema cardiovascular dos cães, dependendo das características do exercício realizado e do condicionamento físico do animal. Pouco se sabe sobre as alterações cardiovasculares causadas pelo treinamento de busca, resgate e salvamento. Objetivou-se, com este estudo, avaliar as respostas cardiovasculares após uma sessão desse tipo de treino, a fim de diferenciar essas alterações de casos de exaustão ou de alguma possível patologia. Foram utilizados nove cães saudáveis em treinamento de busca, resgate e salvamento há pelo menos um ano, sendo sete da raça Pastor Alemão e dois da raça Pastor Belga Malinois. Os cães foram submetidos a dois momentos de avaliação: MO imediatamente antes do exercício e M1 imediatamente após um treinamento de 20 minutos. Em cada avaliação, foram realizados os exames eletrocardiográfico e ecocardiográfico e a aferição da pressão arterial sistólica sistêmica. Apenas a frequência cardíaca foi avaliada em três momentos, em M0, M1 e após cinco minutos do término da atividade física (M2). Os resultados obtidos indicam que o treinamento causa um aumento na demanda de oxigênio, provocando um aumento significativo no débito cardíaco, no volume ventricular esquerdo em diástole e no diâmetro da artéria aorta, assim como um aumento em um dos parâmetros de contratilidade cardíaca (movimento anular de mitral), sem causar prejuízo às funções cardíacas sistólicas e diastólicas. Os valores da FC imediatamente após e cinco minutos após o exercício foram similares aos valores basais. A PASS e os parâmetros eletrocardiográficos não se alteraram após o treinamento. Os achados encontrados indicam

Recebido em 19 de maio de 2017

Aceito em 25 de agosto de 2017

* Autor para correspondência (corresponding author)

E-mail: kapreising@gmail.com 
Effect of exercise...

um bom desempenho cardíaco ao esforço físico dos cães de busca, resgate e salvamento, reduzindo-se as chances de má performance $e$ de ocorrência de morte súbita causada pelo exercício, em resposta ao padrão da atividade realizada.

Palavras-chave: cão de trabalho, ecocardiografia, eletrocardiografia, fisiologia do exercício, pressão arterial

\section{INTRODUCTION}

Rescue-trained dogs have great social impact because of their invaluable help in the search for living persons and/or corpses in different types of disasters (Rovira et al., 2008). Dogs more accurately and quickly detect the location of victims because of their keen sense of smell (Merigueti, 2014). The success of occurrences depends on numerous factors, such as wind direction, burial depth, air humidity (Diverio et al., 2016), dog obedience, dog-conductor connection (Rovira et al., 2008), and good physical conditioning, because the dogs cover large areas in the search for victims during bad weather conditions with little access to land and difficult locomotion (Rovira et al., 2008; Diverio et al., 2016). While these dogs are not working on actual occurrences, they perform daily training that simulates real situations to maintain the dogs' physical training. The effort involved generally involves obstacle courses and races that last 20 to 60 minutes per day (Merigueti, 2014).

Studies of the cardiovascular response to physical exercise in dogs primarily focused on specific sports, such as sled dogs (Van Citter and Frankli, 1969; Constable, 2000), race dogs (Carew and Covell, 1978; Vázques et al., 1998) and agility dogs (Rovira et al., 2010). Heart rate (HR) is an important factor in the evaluation of animal athletes, and dog recovery after physical activity is directly related to good physical conditioning (Muñoz et al., 2006). Electrocardiographic and echocardiographic evaluations revealed the occurrence of cardiac arrhythmias (Vázques et al., 1998) and systolic and diastolic dysfunctions after exercise, which may be physiological or related to primary heart disease (Negrão and Barreto, 2010).

However, few studies examined rescue-trained dogs, and they are especially focused in the metabolic response to the exercise (Rovira et al., 2008; Diverio et al., 2016). It is important to know the cardiac physiological demand of these dogs to differentiate a physiological response from a pathological response, which may lead to heart failure and death. Therefore, this study evaluated the cardiovascular responses in rescuetrained dogs before and after training using electrocardiographic, echocardiographic and systolic blood pressure (SBP) measurements.

\section{MATERIAL AND METHODS}

The Committee on Ethics in the Use of Animals (CEUA) of the Federal University of Espírito Santo evaluated and approved the use of animals for this study under protocol $\mathrm{n}^{\circ} 72 / 2015$. The dogs were placed in the Military Fire Brigade of Espírito Santo, and the commander of the Military Fire Brigade, who was responsible for the animals, clarified the study and authorized the participation of dogs in the project by signing a free term of clarification.

Nine adult dogs were used: seven German Shepherds and two Belgian Shepherd Malinois. Six dogs were females, and three dogs were males. Dogs weighed between 24 and $33.4 \mathrm{~kg}$ $(27.98 \pm 2.85 \mathrm{~kg})$ and aged between 1 year and 2 months to 8 years old (43 months \pm 31.28 ). Dogs practised obedience in search and rescue training for at least 1 year.

A clinical history and complete physical examination (abdominal palpation, palpation of lymph nodes, rectal temperature, cardiopulmonary auscultation, HR, respiratory rate, skin turgor, pulse gauging, capillary filling time) were performed for all dogs included in this study. Blood collection was performed to obtain complete blood count and biochemical analyses (urea, creatinine, alanine aminotransferase [ALT], aspartate aminotransferase [AST], albumin and total proteins). All dogs were evaluated using electrocardiographic, echocardiographic and SBP assessments. Animals with any evidence of disease were excluded from the study. 
Dogs underwent cardiovascular evaluation at two different moments, moment 0 (M0) and moment 1 (M1). The same examiner performed all examinations. M0 was performed with the dogs at rest, and M1 was performed immediately after 20 minutes of search and rescue training. Three extras were arranged in hiding places for training to simulate real disappearance situations, and the dogs searched, exercised, and alternated moments of walking, running, and crossing obstacles. HR was evaluated at three moments, M0, M1 and 5 minutes after the end of physical activity (M2). All dogs were weighed and physically examined at M0 and M1 to assess hydration status. Ambient temperature was determined prior to the tests because it may influence the hydration status of the animals.

An ultrasound device (Esaote Mylab TM 30VET Gold, Brazil) with a sectoral transducer PA240 at a frequency of 1 to $4 \mathrm{MHz}$ was used to perform the echocardiographic examination. Longitudinal and transverse cuts of the heart were performed according to the recommendations of Boon (2011). A single examiner performed the echocardiographic parameters for each dog, which were indexed by dividing the echocardiographic measurements by the body surface area of each individual (Boon, 2011).

The following parameters were evaluated in the $M$ mode in the right parasternal window on the transverse axis: thickness of the interventricular septum in diastole (IVSd) and systole (IVSs), left ventricular internal diameter in diastole (LVIDd) and systole (LVIDs), left ventricular free wall in diastole (LVWd) and systole (LVWs) and E point to septal separation (EPSS). The equipment automatically calculated the shortening fraction (SF). The diameter of the left atrium (LA) and aorta (Ao) were calculated in mode B. The equipment determined the left atrial aortic root ratio (LA/Ao). Spectral Doppler evaluation of the maximum pulmonary flow velocity (ApVmax) and colour Doppler of the pulmonary artery were performed in the cardiac base image. The Simpson method was used to calculate the left ventricular systolic volume (LVVs), left ventricular diastolic volume (LVVd), ejection fraction (EF), cardiac output (CO) and systolic volume (SV) in the axis (Serres et al., 2008).

Images in the left parasternal window were obtained in the apical windows, where the spectral Doppler values of mitral flow, wave A (Mitral A) and wave E (Mitral E), and maximum aortic flow velocity (Ao-Vmax) were obtained. Isovolumic relaxation time (IVRT) and colour Doppler of the mitral and aorta were obtained. The values of mitral annular movement (MAM) in the intraventricular septum (Schober and Fuentes, 2001) and systolic excursion of the annular tricuspid plane (TAPSE) were performed in M mode (Pariaut et al., 2012).

Electrocardiographic examinations were performed using a computerised electrocardiograph (ECG PC Veterinário - TEB Brazilian Electronic Technology () , and the same examiner performed all examinations. The animals were positioned in the right lateral decubitus position, and the electrodes were positioned according to the recommendations of Tilley (1992). Electrocardiographic monitoring had an average duration of two minutes, and the bipolar (I, II, III) and unipolar derivations of limbs (aVR, aVL, aVF) were evaluated. The durations of $\mathrm{P}, \mathrm{PR}, \mathrm{QRS}, \mathrm{QT}$ and the millivolt (mV) amplitudes of $\mathrm{P}, \mathrm{Q}$ and $\mathrm{R}$ were recorded. T wave amplitude was also determined, independent of its polarity. ST-segment deviation relative to the baseline, heart rate, HR and the electrical axis were monitored based on Tilley's (1992) recommendation.

A non-invasive method was used to obtain systolic SBP using vascular ultrasound Doppler (Vascular Doppler, Medmega, Brazil) in the palmar region metacarpal in the left thoracic limb, with the animal in the right lateral decubitus according to Brown et al. (2007). Five SBP measurements were performed on each animal, and the mean of each measurement was obtained for better standardization of results.

The data were submitted to descriptive analysis to obtain means, medians and standard deviation and the Shapiro-Wilk normality test. The means of variables with normal distribution (echocardiographic parameters) were compared at different moments using Student's t test for related samples. Non-normal distributions (electrocardiographic parameters, SBP, weight and ambient temperature) underwent Wilcoxon's non-parametric test to compare different moments. HR values were submitted to Friedman's analysis of variance for comparisons between the different moments of the 
experimental group. All tests were performed with a significance level of $5 \%$. A descriptive analysis of the T-wave, ST-segment, rhythm and cardiac electrical axis on the ECG and Doppler evaluation in the echocardiogram were also performed.

\section{RESULTS AND DISCUSSION}

The mean value of HR $(138 \pm 44.05 \mathrm{bpm})$ (Figure 1) was higher than expected for a large dog at rest at M0, which may be directly related to an early response to the stimulus. The tests were performed at the usual training site of the dogs, in which the pre-exercise HR rises because of the release of adrenaline from the adrenals and norepinephrine by the sympathetic nervous system (Stephenson, 2014).

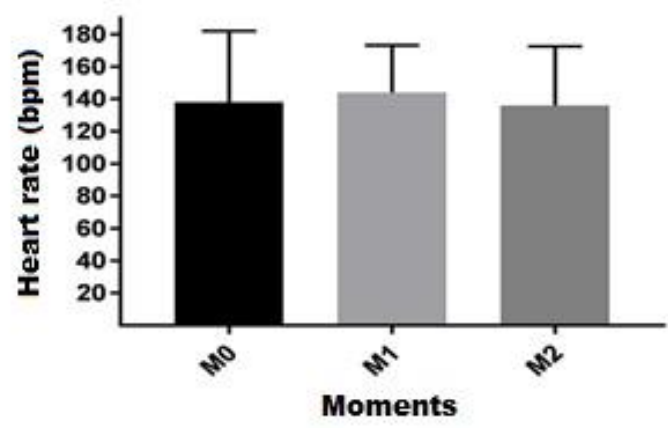

Figure 1. Representation of heart rate values (mean \pm standard deviation) of the German Shepherds and Belgian Shepherd Malinois at rest (M0), immediately after performing a search and rescue training session for 20 minutes (M1), and five minutes after the training session (M2) $(n=9)$. Non-significant difference $(P=0.15)$.

No significant difference in HR values was observed between M0 and M1, but an increase in mean HR was observed $(144 \pm 29.16 \mathrm{bpm})$. HR may have reached its maximum value (HRmax) during physical activity, which could not be determined. $\mathrm{HR}$ is the main determinant of $\mathrm{CO}$ and oxygen consumption $\left(\mathrm{O}_{2}\right)$. Increased $\mathrm{HR}$ is expected during exercise, and it considered an index of cardiovascular workload (Rovira et al., 2008). Several studies demonstrated an increase in HR immediately after physical exertion in dogs (Vázquez et al., 1989; Erickson and Poole, 2006; Rovira et al., 2008; Rovira et al., 2010).

HR was not significantly different between moments immediately after physical exercise, but the highest value was observed in M1, which was submaximum because of the significant increase in $\mathrm{CO}$ in $\mathrm{M} 1$ on the echocardiogram (Table 1). This factor is a good indication of the physical conditioning of these dogs. The increase in HR caused by sympathetic activity is responsible for reduced systole time, which preserves the diastolic filling time and increases CO (Rovira et al., 2010).

It was not possible to observe a significant reduction in HR five minutes after physical exercise (M2) (Figure 1). However, we identified a reduction in the mean in M2 $(136 \pm 36.50 \mathrm{bpm})$, with smaller values than the average of M0, which indicates that these dogs exhibited satisfactory physical conditioning. HR tends to fall rapidly within the first few minutes after physical activity and continues to slow down (Erickson and Poole, 2006). The monitoring of this HR in the recovery period after physical effort is important to evaluate the physical conditioning of the animals, especially dogs submitted to resistance work. An animal that exhibits a good reduction in HR values after exercise has better physical condition than other animals who exhibit greater difficulty (Muñoz et al., 2006). HR recovery after exercise is directly linked to autonomic nervous system control over the heart, and impaired recovery is linked to poorer performance (Chen et al., 2011), which also indicates exhaustion or lack of conditioning (Muñoz et al., 2006; Rovira et al., 2008).

Table 1 shows the echocardiographic parameters evaluated. $\mathrm{CO}$ and the mean values of LVVd, Ao and MAM increased significantly after the training (Table 1). No dogs exhibited alterations in colour Doppler evaluation or valvular alterations. 
Table 1. Echocardiographic parameters (mean \pm standard deviation) of German Shepherd and Belgian Shepherd Malinois dogs at rest (M0) and after search and rescue training (M1) (n=9)

\begin{tabular}{cccc}
\hline Parameters & M0 & M1 & p-value \\
\hline IVSd $(\mathrm{mm})$ & $12.04 \pm 2.43$ & $11.42 \pm 1.45$ & 0.376 \\
LVIDd $(\mathrm{mm})$ & $42.12 \pm 3.91$ & $40.58 \pm 6.51$ & 0.481 \\
LVWd $(\mathrm{mm})$ & $11.08 \pm 1.63$ & $11.18 \pm 1.86$ & 0.895 \\
IVSs $(\mathrm{mm})$ & $16.56 \pm 3.49$ & $15.66 \pm 3.03$ & 0.608 \\
LVIDs $(\mathrm{mm})$ & $26.55 \pm 3.79$ & $25.47 \pm 5.52$ & 0.607 \\
LVWs $(\mathrm{mm})$ & $12.63 \pm 3.76$ & $12.42 \pm 1.78$ & 0.887 \\
SF $(\%)$ & $37.33 \pm 4.44$ & $38.00 \pm 4.58$ & 0.772 \\
EF $(\%)$ & $73.11 \pm 5.18$ & $71.44 \pm 8.60$ & 0.588 \\
EPSS $(\mathrm{mm})$ & $3.06 \pm 0.67$ & $2.58 \pm 1.20$ & 0.359 \\
LA $(\mathrm{mm})$ & $23.78 \pm 2.90$ & $25.83 \pm 2.17$ & 0.164 \\
Ao $(\mathrm{mm})$ & $22.19 \pm 2.08^{*}$ & $24.81 \pm 2.17 *$ & $0.001^{*}$ \\
LA/Ao $(\mathrm{mm})$ & $1.10 \pm 0.10$ & $1.06 \pm 0.13$ & 0.426 \\
Ap-max $(\mathrm{m} / \mathrm{s})$ & $0.93 \pm 0.16$ & $0.97 \pm 0.17$ & 0.446 \\
Ao-max $(\mathrm{m} / \mathrm{s})$ & $1.18 \pm 0.23$ & $1.13 \pm 0.11$ & 0.549 \\
Mitral-A (m/s) & $0.65 \pm 0.07$ & $0.67 \pm 0.12$ & 0.718 \\
Mitral-E $(\mathrm{m} / \mathrm{s})$ & $0.73 \pm 0.12$ & $0.74 \pm 0.10$ & 0.853 \\
E/A $(\mathrm{m} / \mathrm{s})$ & $1.11 \pm 0.13$ & $1.12 \pm 0.17$ & 0.939 \\
IVRT $(\mathrm{ms})$ & $48.00 \pm 6.18$ & $49.56 \pm 4.50$ & 0.435 \\
MAM $(\mathrm{cm})$ & $0.96 \pm 0.06^{*}$ & $1.02 \pm 0.09^{*}$ & $0.016^{*}$ \\
TAPSE $(\mathrm{cm})$ & $16.67 \pm 2.70$ & $17.04 \pm 2.46$ & 0.673 \\
LVVd $(\mathrm{ml})$ & $27.28 \pm 13.90^{*}$ & $34.07 \pm 16.97 *$ & $0.040^{*}$ \\
LVVs $(\mathrm{ml})$ & $7.85 \pm 3.04$ & $10.24 \pm 3.77$ & 0.057 \\
SV $(\mathrm{ml})$ & $24.68 \pm 12.83$ & $22.63 \pm 11.93$ & 0.129 \\
CO $(\mathrm{ml} / \mathrm{min})$ & $2.85 \pm 1.18^{*}$ & $3.62 \pm 1.67 *$ & $0.038^{*}$ \\
\hline
\end{tabular}

Legend: Dogs at rest (M0); Dogs after a search and rescue training session (M1); intraventricular septum in diastole (IVSd); left ventricle internal diameter in diastole (LVIDd); left ventricular free wall in diastole (LVWd); intraventricular septum in systole (IVSs); left ventricle internal diameter in systole (LVIDs); free wall of the left ventricle in systole (LVWs); shortening fraction (SF); ejection fraction (EF); septal separation of point E (EPSS); left atrium (LA); artery aorta (Ao); left atrial aortic root ratio (LA/Ao); maximum pulmonary flow velocity (Ap-max); maximum aortic flow velocity (Ao-max); E wave mitral flow (Mitral-E); mitral flow A (Mitral-A); E to A ratio (E/A); isovolumetric relaxation time (IVRT); mitral annular movement (MAM); systolic excursion of the annular tricuspid plane (TAPSE); left ventricular volumes in diastole (LVVd); left ventricular volumes in systole (LVVs); systolic volume $(\mathrm{SV})$; cardiac output $(\mathrm{CO})$; millilitre $(\mathrm{ml})$; centimetre $(\mathrm{cm})$; millisecond $(\mathrm{ms})$; metres per second $(\mathrm{m} / \mathrm{s})$; millimetre $(\mathrm{mm})$; percent $(\%)$; millilitres per minute $(\mathrm{ml} / \mathrm{min})$. Values with envelopes $*$ in the same row are significantly different, with $\mathrm{p}$-value less than $5 \%$.

The increase in LVVd after exercise may be explained by the increased preload caused by the union of the muscular pump and respiratory pump and the sympathetic responses, which together allow a greater diastolic filling and cause a greater CO. Contraction of the musculature presses the blood vessels contained in its interior and directs the blood to the calibres as veins of the central circulation, which contributes to the preload increase. The respiratory pump occurs due to the increased depth of respiratory movements during exercise. Therefore, the negative pressure formed in the thorax causes a distension of the central vessels and helps direct the blood from the abdominal veins to the central veins, which increases the venous return and preload (Stephenson, 2014).

The highest increase in Ao was observed in M1 and occurred due to the increase of DC during physical activity. The heart needs to direct a larger volume of blood to the active musculature, which occurs via the increase in Ao (Enge, 2006). The Ao functions as a channel for blood distribution and plays an important role in left ventricular function, which avoids damage to left ventricular function due to its distension. Ao dilation was also observed after physical exercise in humans (Kaşikçioğlu et al., 2005). 
The dogs in this study exhibited increased blood demand, which was represented by increased $\mathrm{CO}$ and LVVd. However, this increase was not sufficient to cause significant secondary changes in LV structure, which was observed in sled dogs, which exhibited significant increases in LVIDd, IVSd, IVSs and LVWd after physical activity (Stepien et al., 1998).

A significant increase in MAM and a nonsignificant increase in TAPSE and SF were observed, which suggest an increase in cardiac contractility. Preload directly influences cardiac contraction, and its increase after exercise is associated with a slight increase in HR, which leads to an increase in the force of cardiac contraction according to Frank-Starling's law (Enge, 2006). The release of adrenaline from physical activity also exerts a positive inotropic effect (Stephenson, 2014).

The maintenance of SF and EF in the dogs in this study after training reflects the physiological capacity of the dogs to maintain left ventricular function in response to exercise, which was described by Negrão and Barreto (2010). Sled dogs that demonstrated an evident increase in LV after physical activity did not exhibit FS modification before or after exercise, which also demonstrates the physiological adaptation capacity of these dogs to maintain CO (Stepien et al., 1998).

The dogs were weighed to assess the state of hydration more objectively and more sensitively than the physical examination. A significant reduction in the mean body weight of dogs from $28.1 \mathrm{~kg}$ to $27.5 \mathrm{~kg}$ was noted. Weight loss suggests a loss of fluid due to dehydration. However, this loss was not sufficient to decrease the preload of animals after training. Naylor et al. (1993) found a decrease in CO in horses after exercise due to dehydration, which was not observed in this study because CO was elevated after physical activity. The mean ambient temperature remained at $24^{\circ} \mathrm{C}$ and did not influence the state of heat hydration.

No dog in this study exhibited rhythm or conduction disturbance in the electrocardiographic exam. These changes may be present after physical exercise when preheating is inadequate, when the dynamic exercise approaches the maximum capacity or during the rapid recovery, which is called the arrhythmogenic period (Vázquez et al., 1998; Negrão and Barreto, 2010). Ventricular premature complex (VPC) in non-athlete dogs was observed during and after physical activity, which was likely related to the lack of physical conditioning of the animals (Barretto et al., 2013). Vázquez et al. (1998) also reported the occurrence of 15 VPC cases in racing greyhounds, seven before and eight after testing 399 animals. A decrease in occurrence was observed after five minutes of monitoring, which demonstrated the transient nature of this arrhythmia. Therefore, the dogs in the present study exhibited good physical conditioning through the proposed physical activity.

Five dogs exhibited sinus rhythm $(5 / 9,55.5 \%)$ in M0. One dog exhibited respiratory sinus arrhythmia $(1 / 9 ; 11.1 \%)$, and three dogs exhibited sinus tachycardia $(3 / 9 ; 33.3 \%)$. Seven dogs exhibited sinus rhythm $(7 / 9 ; 77.7 \%)$ in $\mathrm{M} 1$, and two exhibited respiratory sinus arrhythmia $(2 / 9 ; 22.2 \%)$. Two of the dogs that presented sinus tachycardia in M0 started to present sinus rhythm in M1, likely because they were less stressed and apprehensive about the tests in the second evaluation. Sinus arrhythmia is a normal rhythm variation in dogs, and it is influenced by vagal tonus and disappears after physical exercise due to the release of catecholamines in response to sympathetic stress with inhibition of vagal tone (Vázquez et al., 1998).

Table 2 shows the electrocardiographic parameters. There were no significant differences in these parameters between the moments evaluated in this study. However, Constable et al. (2000) found a prolongation of QT interval after exercise in dogs practising resistance testing. The authors suggested that this change may be caused by alterations in rhythm cardiac, heart size and electrolyte concentrations (primarily calcium and potassium ions) (Constable et al., 2000). An increase in QRS complex duration in dogs practising routine physical activity due to exercise-induced physiologic cardiac hypertrophy was also reported (Constable et al., 1994). 
Table 2. Electrocardiographic parameters (median \pm standard deviation) of German Shepherd and Belgian Shepherd Malinois dogs before (M0) and after a search and rescue training session for 20 minutes (M1) $(\mathrm{n}=9)$

\begin{tabular}{cccc} 
Parameters & M0 & M1 & -value \\
\hline P wave $(\mathrm{s})$ & $0.045 \pm 0.008$ & $0.040 \pm 0.009$ & 0.600 \\
P wave $(\mathrm{mV})$ & $0.180 \pm 0.092$ & $0.190 \pm 0.091$ & 0.812 \\
PR interval (s) & $0.093 \pm 0.014$ & $0.095 \pm 0.016$ & 0.888 \\
R wave $(\mathrm{mV})$ & $1.410 \pm 0.305$ & $1.410 \pm 0.348$ & 0.313 \\
Q wave $(\mathrm{mV})$ & $0.210 \pm 0.214$ & $0.180 \pm 0.180$ & 0.952 \\
S wave $(\mathrm{mV})$ & $0.000 \pm 0.052$ & $0.000 \pm 0.062$ & 0.593 \\
QRS complex $(\mathrm{s})$ & $0.060 \pm 0,012$ & $0.055 \pm 0.012$ & 0.262 \\
QT interval (s) & $0.190 \pm 0.022$ & $0.192 \pm 0.010$ & 0.888 \\
T wave $(\mathrm{mV})$ & $0.192 \pm 0,105$ & $0.250 \pm 0.131$ & 0.952 \\
Electrical axis $\left({ }^{\circ}\right)$ & $78.00 \pm 15.59$ & $79.00 \pm 8.39$ & 0.051
\end{tabular}

Legend: Dogs at rest (M0); dogs after a search and rescue training session (M1); Seconds (s); Millivolt (mV); degrees $\left({ }^{\circ}\right)$.

ST segment was not below or elevated in any dog of the present study. Changes in the ST segment are common in humans, which indicate early ventricular repolarisation and ischaemia. These findings are directly related to exercise duration and intensity (Negrão and Barreto, 2010). None of the enduro racing horses exhibited alterations in the ST segment (Dumont et al., 2010), which indicates good conditioning of these animals and coincides with the dogs in this study.

Six dogs $(6 / 9 ; 66.6 \%)$ exhibited a change in $\mathrm{T}$ wave polarity. The waves were positive in three dogs and became biphasic. The wave was negative and became biphasic in one case. A biphasic wave became positive in one case, and the wave was positive and turned negative in one case. Changes in the $\mathrm{T}$ wave may be associated with a variety of physiological and pathological factors, such as physical exertion, excitation, drugs, vagal tone, myocardial hypoxia, electrolytic disturbances and myocarditis (Gilmour Jr. and Möise, 2006). T wave polarity was associated with physical exercise in this study, which was also observed in humans (Negrão and Barreto, 2010) and equines (Binda et al., 2016). However, the influence of changes in $\mathrm{T}$ wave polarity on athletic performance is non-specific and of no diagnostic value for myocardial ischaemia (Negrão and Barreto, 2010).

All dogs in the present study exhibited a normal cardiac axis, according to Tilley (1992), without significant alterations after physical activity. Resistance test horses exhibited right and left electrical axis deviation before and after exercise, which suggests right and left ventricular overload, respectively. These findings are consistent with cardiac hypertrophy caused by physical activity (Dumont et al., 2010).

Figure 2 shows the SBP values of the dogs in the present study. An increase in the median was observed after training, but this increase was not significantly different between the evaluated moments $\quad(\mathrm{M} 0=116 \pm 17.49 \mathrm{mmHg} \quad$ and $\mathrm{M} 1=130 \pm 17.60 \mathrm{mmHg}$ ).

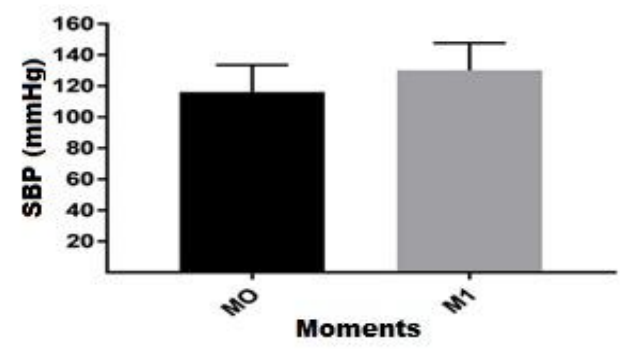

Figure 2. Systemic systolic blood pressure (median \pm standard deviation) of German Shepherd and Belgian Shepherd Malinois dogs before (M0) and after a 20-minute search and rescue training session $(\mathrm{M} 1)(\mathrm{n}=9)$. Nonsignificant difference $(\mathrm{P}=0.32)$.

An increase in SBP is expected during physical activity because of the need for increased blood flow to the active muscles, which increases $\mathrm{CO}$, $\mathrm{HR}$ and SV and vasodilation of the active muscles, which decreases peripheral vascular resistance. Therefore, haemodynamic adjustment increases SBP and preserves diastolic blood 
pressure. Higher physical exercise intensity increases the need for blood and $\mathrm{CO}$, which increased higher SBP (Forjas and Tinucci, 2000). An increase in SBP was reported in sled dogs after running, which indicates that the SBP elevation in dogs occurs similarly to humans (Van Citter and Franklin, 1969).

\section{CONCLUSION}

The results of this study demonstrated that search and rescue training significantly increased the echocardiographic parameters of $\mathrm{CO}, \mathrm{Ao}, \mathrm{LVVd}$ and MAM after physical activity in dogs without impairing cardiac function. $\mathrm{HR}$ values immediately and five minutes after exercise were similar to baseline values. Therefore, the findings of the cardiovascular evaluation indicate good physical conditioning of search and rescuetrained dogs when performing 20 minutes of training.

\section{ACKNOWLEDGEMENTS}

The authors wish to thank the Military Fire Brigade of Espírito Santo, Lieutenant Colonel Leonardo de Alcântara Merigueti and the entire K9 team, for allowing this study to be carried out, and we thank all the dogs search and rescue. This paper is dedicated to all people and dogs that, in case disasters, never hesitate to generously risk their own lives to save those in need.

\section{REFERENCES}

BARRETTO, F.L.; FERREIRA, F.S.; FREITAS, M.V. et al. Eletrocardiografica contínua (holter) em cães saudáveis submetidos a diferentes exercícios físicos. Arq. Bras. Med. Vet. Zootec., v.65, p.1625-1634, 2013.

BINDA, M.B.; TEIXEIRA, F.A.; CARVALHO, R.S. et al. Effects of 3-barrel racing exercise on electrocardiographic and on blood parameters of quarter horses. J. Equine Vet. Sci., v.47, p.71-76, 2016.

BOON, J.A. Veterinary echocardiography. 2.ed. Colorado: Wiley-Blackwell, 2011. 632p.

BROWN S.; ATKINS C.; BAGLEY R. et al. Guidelines for the identification, evaluation, and management of systemic hypertesion in dogs and cats. J. Vet. Intern. Med., v.21, p.542-558, 2007.
CAREW, T.E.; COVELL, J.W. Left ventricular function in exercise-induced hypertrophy in dogs. Am. J. Cardiol., v.42, p.82-88, 1978.

CHEN, J.Y.; LEE, Y.L.; Tsai, W.C. et al. Cardiac autonomic functions derived from shortterm heart rate variability recordings associated with heart rate recovery after treadmill exercise test in young individuals. Heart Vessels, v.16, p.282-288, 2011.

CONSTABLE, P.D.; HINCHCLIFF, K.W.; OLSON, J.L.; HAMLIN, R.L. Athletic heart syndrome in dogs competing in a long-distance sled race, J. Appl. Physiol., v.76, p.433, 1994.

CONSTABLE, P.D.; HINCHCLIFF, K.W.; OLSON, J.L.; STEPIEN, R.L. Effects of endurance training on standard and signalavarage electrocardiograms of sled dog. A. J. Vet. Res., v.61, p.581-588, 2000.

DIVERIO, S.; BARBATO, O.; CAVALLINA, R. et al. A simulated avalanche search and rescue mission induces temporary physiological and behavioural changes in military dogs. Physiol. Behav., v.163, p.193-202, 2016.

DUMONT, C.B.S.; LEITE, C.R.; MORAES, J.M. et al. Parâmetros eletrocardiográficos de equinos puro sangue árabe submetidos a exercício de enduro. Cienc. Rural, v.40, p.19661973, 2010.

ENGE, R.L. Dinâmica do sistema cardiovascular. In: REECE, W.O. Dukes fisiologia dos animais domésticos. 12.ed. Rio de Janeiro: Guanabara Koogani, 2006. cap.10, p.163-172.

ERICKSON, H.H.; POOLE, D.C. Fisiologia do exercício. In: REECE, W.O. Dukes - fisiologia dos animais domésticos. 12.ed. Rio de Janeiro. Guanabara Koogani, 2006. cap.22, p.330-350.

FORJAS, C.L.M.; TINUCCI, T.A medida da pressão arterial no exercício. Rev. Bras. Hipertens, v.1, p.79-87, 2000.

GILMOUR JR., R.F.; MÖISE, N.S. Eletrocardiograma e arritmias cardíacas. In: REECE, W.O. Dukes - fisiologia dos animais domésticos. 12.ed. Rio de Janeiro. Guanabara Koogani, 2006. cap.13, p.197-207.

KAŞIKÇIOĞLU, E.; KAYSERILIOGLU, A.; OFLAZ, H.; AKHAN, H. Aortic distensibility and left ventricular diastolic functions in endurance athletes. Int. J. Sports Med., v.26, p.165-170, 2005. 
MERIGUETI, L.A. Manual técnico de resgate com cães. Vitória: Corpo de Bombeiros Militar do Espírito Santo, 2014. 82p.

MUÑOZ A.; CUESTA, I.; RIBER, C. et al. Trot asymmetry in relation to physical performance and metabolism in equine endurance rides. Equine Vet. J., v.36, Supl., p.50-54, 2006.

NAYLOR, J.R.; BAYLY, W.M.; GOLLNICK, P.D. et al. Effects of dehydration on thermoregulatory responses of horse during lowintensity exercise. J. Appl. Physiol., v.75, p.9941001, 1993.

NEGRÃO, C.E.; BARRETO, A.C.P. Cardiologia do exercício: do atleta ao cardiopata. 3.ed. São Paulo: Manole, 2010. 725p.

PARIAUT, R.; SAELINGER, C.; STRICKLAND, K.N. et al. Tricuspid Annular Plane Systolic Excursion (TAPSE) in dogs: reference values and impact of pulmonary hypertension. J. Vet. Intern. Med., v.26, p.11481154, 2012.

ROVIRA, S.; MUÑOZ, A.; BENITO, M. Effect of exercise on physiological, blood and endocrine parameters in search and rescuetrained dogs. Vet. Med., v.53, p.333-346, 2008.

ROVIRA, S.; MUÑOZ, A.; RIBER, C.; BENITO, M. Heart rate, electrocardiographic parameters and arrhythmias during agility exercises in trained dogs. Rev. Méd. Vét., v.161, p.307-313, 2010.
SCHOBER, K.E.; FUENTES, V.L. Mitral Annulus motion as determined by M-Mode echocardiography in normal dogs and dogs with cardiac disease. Vet. Radiol. Ultrasound, v.42, p.52-61, 2001.

SERRES, F.; CHETBOUL, V.; TISSIER, R. et al. Comparison of 3 ultrasound methods for quantifying left ventricular systolic function: correlation with disease severity and prognostic value in dogs with mitral valve disease. J. Vet. Intern. Med., v.22, p.566-577, 2008.

STEPHENSON, R.B. Fisiologia cardiovascular. In: KLEIN, B.G. Cunningham - tratado de fisiologia veterinária. 5.ed. Rio de Janeiro: Elsevier, 2014, p.158-262.

STEPIEN, R.L.; HINCHCLIFF, K.W.; CONSTABLE, P.D.; OLSON J. Effect of endurece training cardiac morphology in alaskan sled dog. J. Appl. Physiol., v.85, p.1368-1375, 1998.

TILLEY, L.P. Essentials of canine and feline electrocardiography: interpretation and treatment. 3.ed. Philadelphia: Lea \& Febiger, 1992. 470p.

VAN CITTER, R.L.; FRANKLIN, D.L. Cardiovascular performance of Alaska sled dog during exercise. Circ. Res., v.24, p.33-42, 1969.

VÁZQUEZ, J.P.; GÓMEZ, F.P.; BADILLO, A.A. et al. Arritmias cardíacas inducidas por el ejercicio dinâmico máximo de corta duración (sprint): estúdio em el galgo greyhound. Rev. Esp. Cardiol., v.51, p.559-565, 1998. 